\title{
Water quality assessment and hydrochemical characteristics of groundwater on the aspect of metals in an old town, Foshan, south China
}

\author{
Guanxing Huang, Zongyu Chen* and Jichao Sun \\ Institute of Hydrogeology and Environmental Geology, Chinese Academy of Geological Sciences, \\ Shijiazhuang 050061, China. \\ *Corresponding author.e-mail: chenzy88@hotmail.com
}

\begin{abstract}
The present study is aimed at assessing the water quality and discussing the hydrochemical characteristics and seasonal variation of shallow groundwater on the aspect of metals in the eastern Chancheng district of Foshan city, south China. Multivariate analytical methods such as principal components analysis (PCA) and hierarchical cluster analysis (HCA) were used in this study. The results show that $45 \%$ of groundwater in the east-central of study area is not suitable for drinking purpose due to high concentrations of $\mathrm{Fe}$, $\mathrm{Pb}$ and $\mathrm{Mn}$. The mean concentrations of $\mathrm{Fe}, \mathrm{Hg}, \mathrm{Cu}, \mathrm{Pb}$, and $\mathrm{Mn}$ in dry season are higher than that in wet season. On the contrary, the mean concentrations of $\mathrm{Cd}, \mathrm{Co}, \mathrm{Zn}, \mathrm{Ba}, \mathrm{Cr}, \mathrm{Mo}, \mathrm{Ni}$ and $\mathrm{Al}$ in wet season are higher than that in dry season. PCA results show that four PCs are responsible for the $78.6 \%$ of the total hydrochemical variables in groundwater. Three groups were generated from HCA method. Group 1 reflects the characteristic of wet season and the low ion exchange capacity; group 2 is mainly influenced by the dry season. Reducing environment and high ion exchange capacity are responsible for group 3. The results are useful in addressing future measures in groundwater resource management for local government.
\end{abstract}

\section{Introduction}

Foshan of the Guangdong Province in China is an industrial and commercial city. Over the past decades, with the rapid industrialization and urbanization in Foshan city, more water resource for industrial and domestic uses is required. Due to inadequate availability of surface water, to meet the requirement of industrial production and human living, groundwater remains the only option to supplement the ever-increasing demand of water. In another aspect, because it is free of charge, plenty of urban residents in Foshan city depend heavily on groundwater for drinking and domestic purposes (Sun et al. 2009). It has been observed that metal contamination of groundwater more often than not goes unnoticed and remains hidden from the public view, especially in urban groundwater due to lack of efficient solid waste disposal systems and sewage treatment plants (Edet et al. 2003).

Metals are useful to human beings for the maintenance of health and when a measurable deficit in the diet is allowed, even well-known toxic metals, such as Mo, Co, Cr, Ni, etc. are needed in minute quantities for the normal functioning of cell metabolism (Wang 2004; Pizzol et al. 2011).

Keywords. Groundwater; metal; water quality; hydrochemical characteristics; seasonal variation; principal components analysis. 
However, these metals are known to cause a wide range of adverse effects on human health in higher doses (Pizzol et al. 2011). When metals are discharged into a system, they can migrate or precipitate according to their geochemical mobility and deposit in different components of the systems; unlike organic compounds, they are not degraded, and have the ability to accumulate in the body after getting into human beings.

In recent years, the studies related to metals in groundwater were mainly focused on the hydrochemical assessment and the relationship between metals and other chemical parameters with multivariable statistical analysis (Helena et al. 2000; Edet et al. 2003; Chen et al. 2007; Qian et al. 2010, 2011; Zhang et al. 2012). A handful of studies discussed the seasonal influence on the metals in groundwater (Leung and Jiao 2006; Buragohain et al. 2010). However, to date, not much attention has been paid to discuss the hydrochemical characteristics of metals in groundwater based on the combination of seasonal impact and multivariable statistical analysis, especially in an old town, which has been the primary focus of this study. Furthermore, to date, in the study area, works on metal concentrations have been carried out mainly on the surface water and sediments (Cheung et al. 2003; Ouyang et al. 2006), but no available data about the metal concentrations in groundwater. Therefore, the objectives of this study are to investigate the distribution and seasonal variation of metal concentration in shallow groundwater of an old town in Foshan, to assess the groundwater quality based on the metal concentrations, and to discuss the sources of metals in groundwater by using multivariate analytical methods. Because the metal composition of groundwater depends not only on natural factors such as the aquifer properties, the quality of recharge waters and the types of interaction between water and rocks, but also on human activities, which can alter these fragile groundwater systems, either by polluting them or by changing the hydrological cycle (Helena et al. 2000; Chen et al. 2007). Therefore, sophisticated data analysis techniques such as multivariate analytical methods are required to effectively interpret metal data in groundwater. The results will get acquainted with the groundwater quality on the aspect of metals, and will be beneficial to improve the groundwater management for the local government.

\section{Materials and methods}

\subsection{Study area}

The study area, eastern Chancheng district, is located in the centre of Foshan city and near the
Pearl River, south China. It belongs to the coastal area with the deposition of fine particles (silty sand and clay), leading to the slow groundwater flow rate and the formation of stagnant shallow groundwater. Geographically, it is situated between longitudes of $113^{\circ} 01^{\prime}-113^{\circ} 10^{\prime} \mathrm{E}$ and latitudes of $22^{\circ} 58^{\prime}-$ $23^{\circ} 04^{\prime} \mathrm{N}$, covers an area of $75.7 \mathrm{~km}^{2}$, and belongs to the Xijiang River basin. The total population is about 768,700 (Sun et al. 2009). The climate is subtropical maritime monsoon climate. The mean annual precipitation is $1777 \mathrm{~mm}$, with $82-85 \%$ of precipitation occurring in April to September (Peng and Wang 2004). The average annual temperature is $23.2^{\circ} \mathrm{C}$. The average temperature is $13.2^{\circ} \mathrm{C}$ in January, while the average temperature is $28.5^{\circ} \mathrm{C}$ in July (Sun et al. 2009).

\subsection{Sampling}

In this study, 29 groundwater samples were collected from civil wells at 20 sites of eastern Chancheng district during wet (July-August 2008) and dry (November-December 2008) seasons; among them, samples were collected from 9 sites in both seasons, others in dry season only (figure 1). Samples were collected below water table at the depth of $50 \mathrm{~cm}$ by a stainless steel sampler (without corrosion or rust) and filtrated by using $0.45 \mu \mathrm{m}$ filter membranes, and then stored in clean and sterile 1-L polyethylene bottles which were rinsed at least three times with groundwater before sampling. After collection, each sample was immediately acidified to $\mathrm{pH}<2$ with ultrapure nitric acid and then stored at approximately $4^{\circ} \mathrm{C}$ before analysis. All probable safety measures were taken at every stage, starting from sample collection, storage, transportation and final analysis of the samples to avoid contamination. In-situ measurements of static water table were made using a sonic water-table indicator prior to sampling during dry season.

\subsection{Analytical procedures}

Samples were analyzed at the Institute of Hydrogeology and Environmental Geology and all metal concentrations were determined by inductively coupled plasma optical emission spectrometry (ICP-OES) (Perkin-Elmer Optima 5300 DV, USA). The analytical data quality was ensured through careful standardization, procedural blank measurements, spiked and duplicate samples. The recovery rates of the analyzed metals in the standard reference material (USA NIST SRM 1643d) were $>95 \%$. Three replications of each analysis were performed and the mean values were used for calculations. 


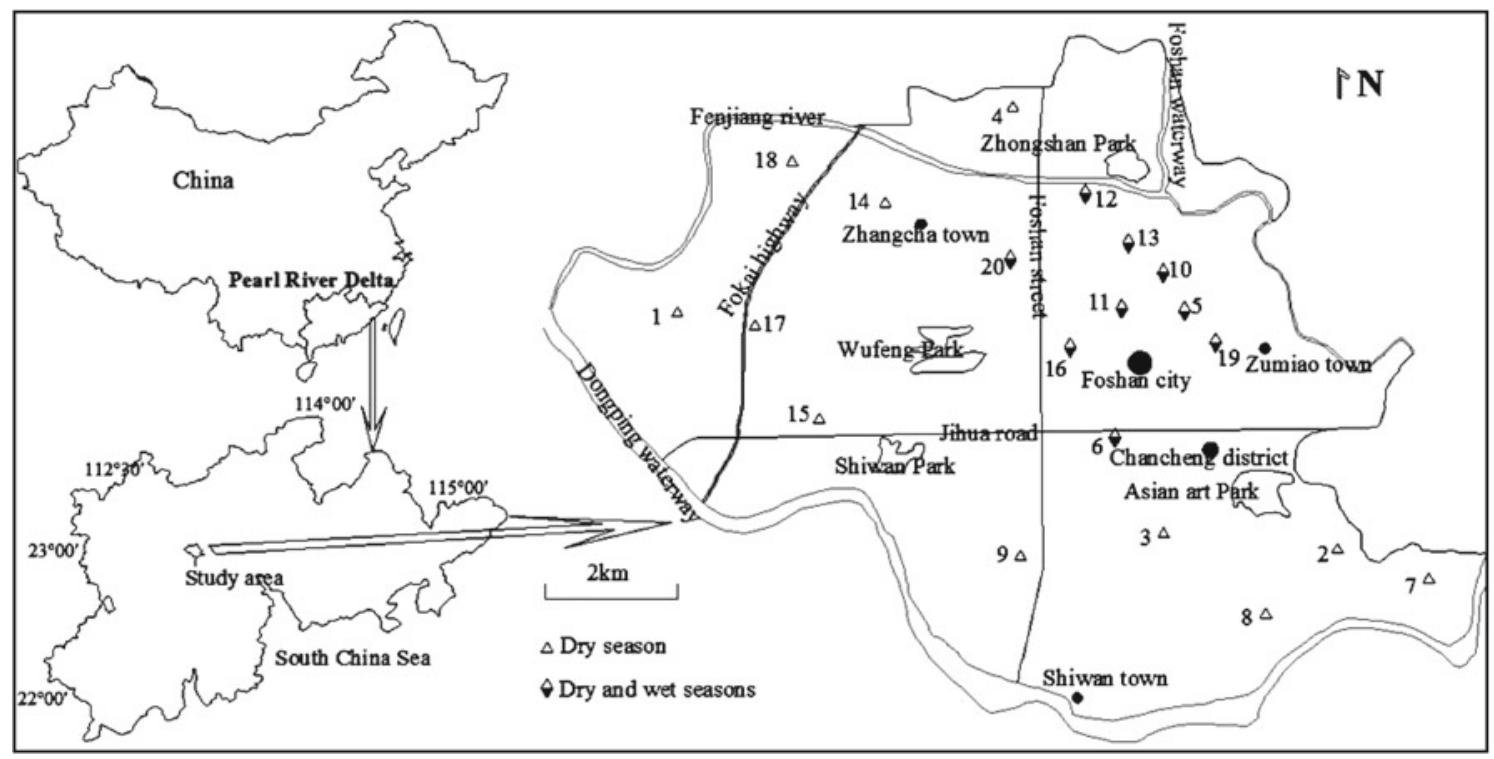

Figure 1. Schematic diagram of the sampling sites in eastern Chancheng district, Foshan, south China.

\subsection{Statistical analysis}

Multivariate analytical methods were used in this study to effectively interpret metal data in groundwater. Hierarchical cluster analysis (HCA) was used in this study to classify samples into different groups based on all the chemical parameters and to indicate the natural associations between samples (Güler et al. 2002; Reghunath et al. 2002; Chen et al. 2007; Zhang et al. 2012). Principal components analysis (PCA) is useful in reducing data dimension while retaining important information and representing variables in a form that can be easily interpreted (Singh et al. 2005). The statistical software package SPSS 17.0 for windows (SPSS Inc, Chicago, USA) was used for the multivariate statistical calculations. The statistical analysis of HCA and PCA were carried out by the classification and data reduction modules, respectively.

\section{Results and discussion}

\subsection{Distribution of metals in groundwater}

The minimum, mean, and maximum values of 14 metal concentrations in groundwater of the study area during the dry and wet seasons are shown in table 1 together with the laboratory detection limits (DL), the Chinese drinking water limits (DWL) (Ministry of Land and Resources of the People's Republic of China 2008) and the percentages of samples above the DL and DWL. The concentrations of eight metals $(\mathrm{Cu}, \mathrm{Ba}, \mathrm{Cr}, \mathrm{Pb}, \mathrm{Mo}, \mathrm{Mn}$, $\mathrm{Ni}, \mathrm{Al})$ in all groundwater samples during the dry season are above the DL, while the concentrations of other metals (Be, $\mathrm{Cd}, \mathrm{Co}, \mathrm{Fe}, \mathrm{Hg}, \mathrm{Zn}$ ) in some groundwater samples during the dry season are below the DL, especially for Be which is almost in all of the samples below the DL except in sampling site 13. Most of metal concentrations in all of groundwater samples during dry season are below the DWL except Fe, $\mathrm{Pb}$ and $\mathrm{Mn}$. Fe and $\mathrm{Pb}$ concentrations in $20 \%$ of samples exceed the DWL, and Mn concentration in $40 \%$ of samples exceeds the DWL during the dry season. About $45 \%$ of groundwater in the study area is not suitable for drinking purpose due to the high concentrations of $\mathrm{Fe}, \mathrm{Pb}$ and $\mathrm{Mn}$, which is located in the east-central part of the study area, while the groundwater which is suitable for drinking purpose is located in the west and south of the study area except the sampling site 5 (figure 2). The mean metal concentrations in groundwater during the dry season is $\mathrm{Fe}>\mathrm{Mn}>$ $\mathrm{Al}>\mathrm{Zn}>\mathrm{Ba}>\mathrm{Pb}>\mathrm{Cr}>\mathrm{Cu}>\mathrm{Ni}>\mathrm{Mo}>$ $\mathrm{Co}>\mathrm{Cd}>\mathrm{Hg}>\mathrm{Be}$.

Nine sites in the study area were sampled not only in dry season but also in wet season in order to examine the seasonal effects on groundwater metal concentrations (figure 1). During the wet season, the concentrations of four metals (Be, Cd, Fe, $\mathrm{Hg})$ in some groundwater samples are below the $\mathrm{DL}$, especially for $\mathrm{Be}$ and $\mathrm{Hg}$, the concentrations of which in all of the samples are below the DL, while the concentrations of other metals (Co, Zn, $\mathrm{Cu}, \mathrm{Ba}, \mathrm{Cr}, \mathrm{Pb}, \mathrm{Mo}, \mathrm{Mn}, \mathrm{Ni}, \mathrm{Al}$ ) in all groundwater samples are above the DL. The mean metal concentrations in groundwater during the wet season is $\mathrm{Fe}>\mathrm{Mn}>\mathrm{Al}>\mathrm{Zn}>\mathrm{Ba}>\mathrm{Cr}>\mathrm{Cu}>$ $\mathrm{Mo}>\mathrm{Ni}>\mathrm{Pb}>\mathrm{Co}>\mathrm{Cd}>(\mathrm{Hg}, \mathrm{Be})$, which is 


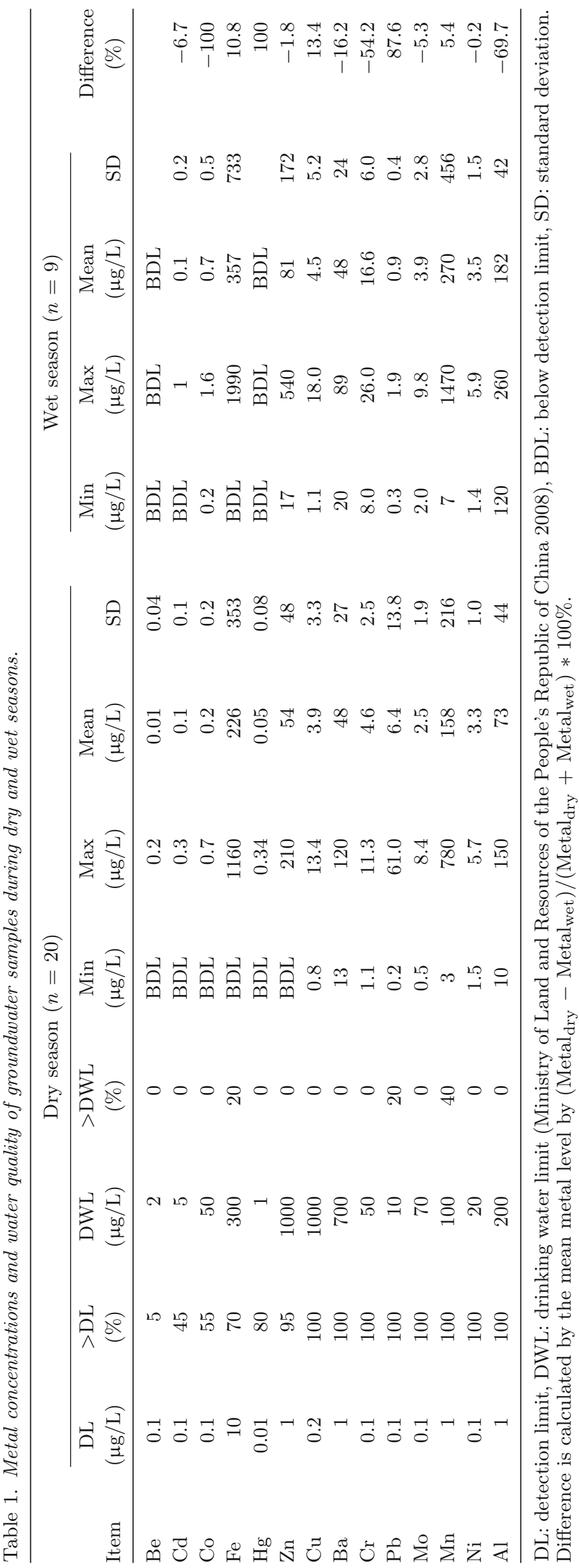




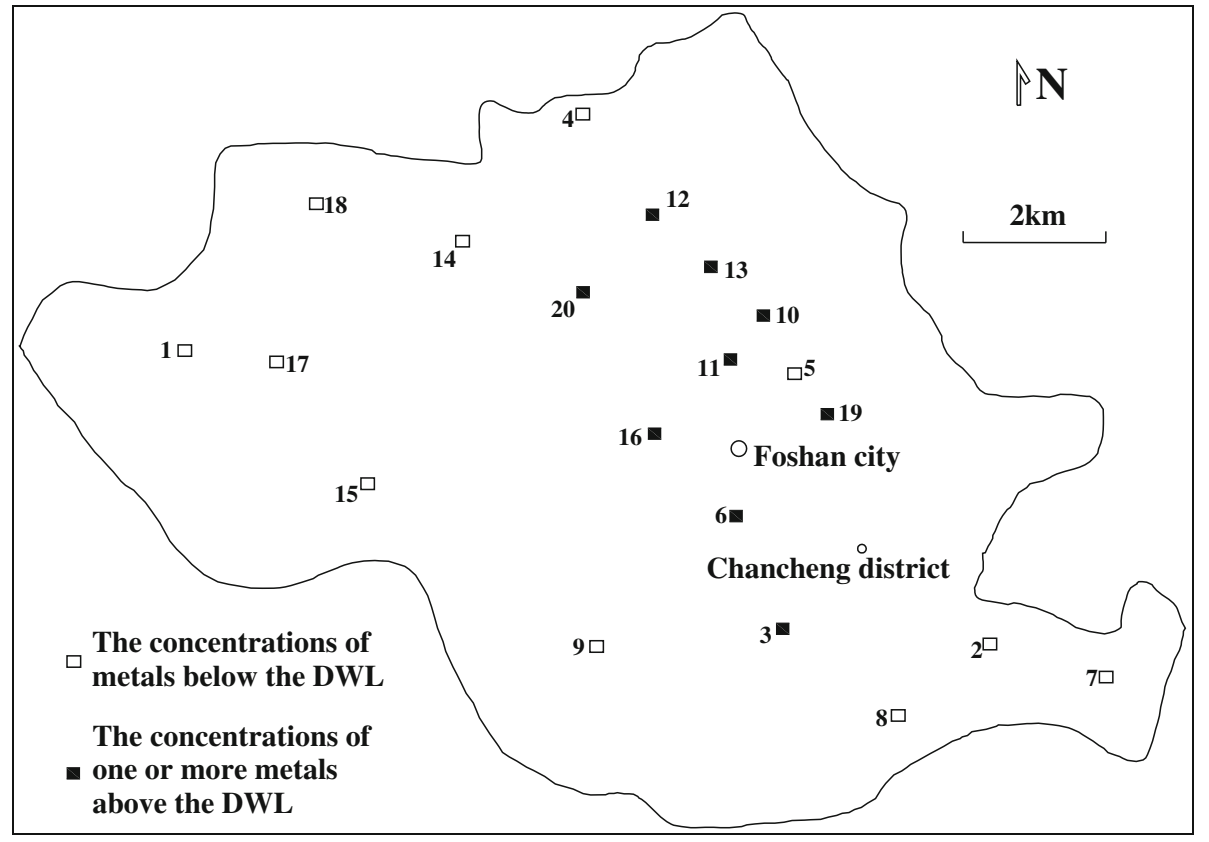

Figure 2. Spatial distribution of metal concentrations in groundwater of the study area during the dry season.

similar to that during the dry season except the $\mathrm{Pb}$. The seasonal comparisons of metal concentrations in the study area are presented in table 1. The mean concentrations of $\mathrm{Fe}, \mathrm{Hg}, \mathrm{Cu}, \mathrm{Pb}$, and $\mathrm{Mn}$ in dry season are higher than that in wet season, especially for $\mathrm{Hg}$ and $\mathrm{Pb}$, the differences are more than $50 \%$, which is consistent with the results reported by Leung and Jiao (2006) and Buragohain et al. (2010) who also observed that the mean concentrations of $\mathrm{Fe}, \mathrm{Cu}$ and $\mathrm{Pb}$ in groundwater in dry season were higher than that in wet season in Hong Kong and Assam of India. One of the possible reasons is that these metals in groundwater of the study area may be controlled by the aquifer itself (Thamdrup 2000; Homoncik et al. 2010), because metal concentrations in the aquifer will be diluted in wet season more easily compared with that in dry season due to higher groundwater recharge in wet season (Huang et al. 2008). On the contrary, the mean concentrations of $\mathrm{Cd}$, Co, $\mathrm{Zn}, \mathrm{Ba}, \mathrm{Cr}$, $\mathrm{Mo}, \mathrm{Ni}$ and $\mathrm{Al}$ in wet season are higher than that in dry season, especially for $\mathrm{Co}, \mathrm{Cr}$ and $\mathrm{Al}$, the differences are also more than $50 \%$. One of the possible reasons pointed out by Leung and Jiao (2006) is that more metals could be leached out from vadose zone into groundwater in the wet season because of the generally higher water table during the wet season. Another explanation is that more metals in groundwater may be recharged from the leakage of sewer pipe during the wet season. For instance, according to our field investigation (Sun et al. 2009), plenty of alloy factories such as aluminum alloy and stellite are located in the study area and in the sample sites G6 and G16, generally occur the leakage of sewer pipe during the wet season due to the abundant rainwater and senescent pipes. As a consequence, the $\mathrm{Co}, \mathrm{Cr}$ and $\mathrm{Al}$ concentrations of them in wet season (mean values of 1.4, 23.0 and $235 \mu \mathrm{g} / \mathrm{L})$ are far higher than that in dry season (mean values of BDL, 5.6 and $33 \mu \mathrm{g} / \mathrm{L}$ ). Correspondingly, ammonia nitrogen, as an indicator for sewer, the content of which in G6 and G16 in wet season (mean value of $9.25 \mathrm{mg} / \mathrm{L}$ ) are also far higher than that in dry season (mean value of $3.02 \mathrm{mg} / \mathrm{L}$ ) (Huang et al. 2013).

As it can be seen from figure 3, the hydrochemical type in wet season is similar to that in dry season. It is shown that, overall, there are more alkaline-earth metal ions than alkaline metal ions; the total concentration of weak acids is higher than that of strong acids; and the carbonate hardness exceeds $50 \%$ in the study area. Meanwhile, $\mathrm{Ca}-$ $\mathrm{HCO}_{3}$ is the dominant chemical type in groundwater in both dry and wet seasons (Huang et al. 2013).

\subsection{Correlation between variables}

Correlation measures the degree of interrelation between two variables (Edet et al. 2003). In this study, Pearson's correlation coefficients $(r)$ between metals were calculated by SPSS 17.0. As far as the selection of variables is concerned, we ruled out $\mathrm{Be}, \mathrm{Cd}$, $\mathrm{Co}$ and $\mathrm{Hg}$ due to the low detection ratios $(<60 \%$, see table 1$)$, but retained other 


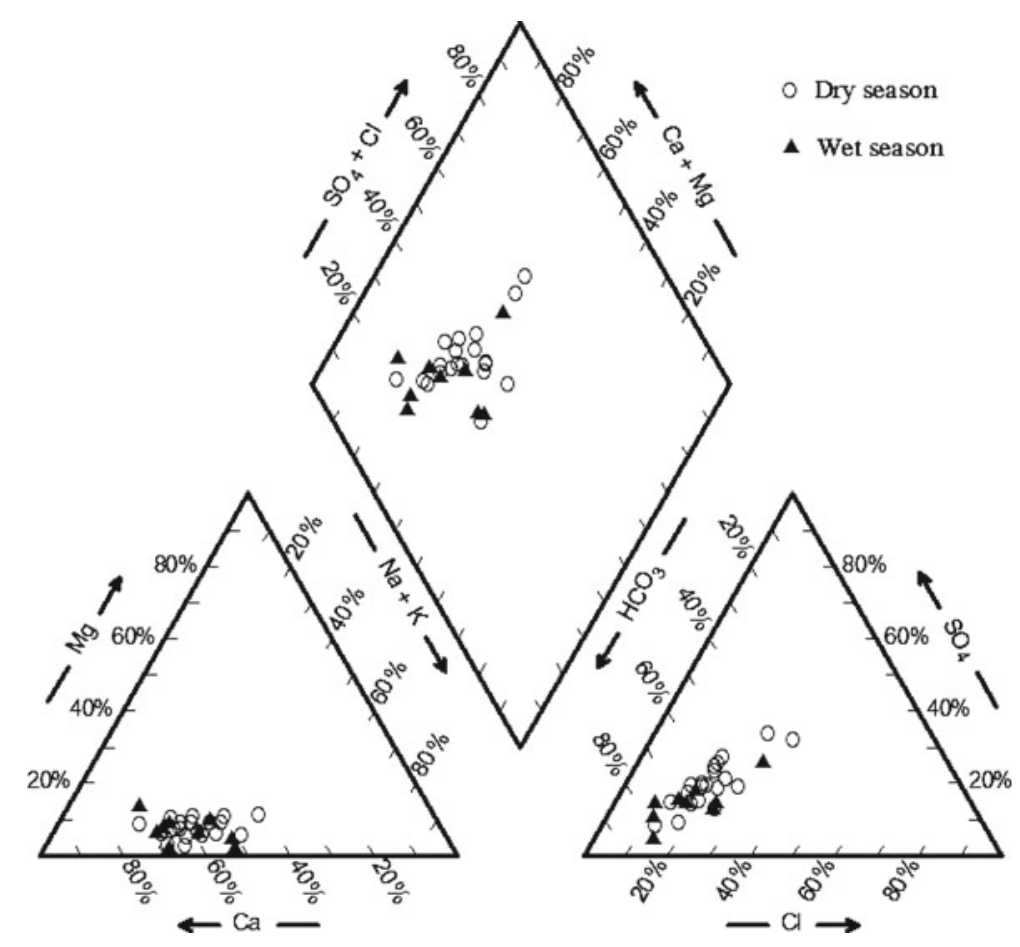

Figure 3. Piper trilinear diagram of the chemical types in groundwater of the study area.

Table 2. Pearson correlation coefficients for the 10 metals in groundwater of study area.

\begin{tabular}{|c|c|c|c|c|c|c|c|c|c|c|}
\hline Item & $\mathrm{Zn}$ & $\mathrm{Cu}$ & $\mathrm{Ba}$ & $\mathrm{Cr}$ & $\mathrm{Pb}$ & Mo & Mn & $\mathrm{Ni}$ & $\mathrm{Al}$ & $\mathrm{Fe}$ \\
\hline $\mathrm{Zn}$ & 1 & & & & & & & & & \\
\hline $\mathrm{Cu}$ & $0.797^{* *}$ & 1 & & & & & & & & \\
\hline $\mathrm{Ba}$ & -0.113 & -0.253 & 1 & & & & & & & \\
\hline $\mathrm{Cr}$ & -0.043 & -0.058 & 0.126 & 1 & & & & & & \\
\hline $\mathrm{Pb}$ & -0.056 & 0.113 & -0.273 & -0.209 & 1 & & & & & \\
\hline Mo & -0.049 & -0.109 & 0.242 & $0.545^{* *}$ & -0.004 & 1 & & & & \\
\hline $\mathrm{Mn}$ & 0.019 & 0.079 & 0.161 & $0.386 *$ & 0.120 & $0.673^{* *}$ & 1 & & & \\
\hline $\mathrm{Ni}$ & 0.200 & 0.352 & 0.159 & 0.319 & 0.230 & $0.540^{* *}$ & 0.357 & 1 & & \\
\hline $\mathrm{Al}$ & -0.032 & -0.098 & 0.333 & $0.777^{* *}$ & $-0.424^{*}$ & 0.234 & 0.180 & 0.239 & 1 & \\
\hline $\mathrm{Fe}$ & 0.023 & 0.030 & 0.233 & 0.341 & -0.058 & $0.690 * *$ & $0.718^{* *}$ & 0.299 & 0.096 & 1 \\
\hline
\end{tabular}

${ }^{* *}$ Correlation is significant at the 0.01 level; ${ }^{*}$ Correlation is significant at the 0.05 level.

10 variables. The correlation matrix (table 2 ) shows that the metals such as $\mathrm{Cr}, \mathrm{Mo}, \mathrm{Al}$ and $\mathrm{Ni}$ which display higher concentrations in wet season than that in dry season are positively correlated with each other $(\mathrm{Cr}$ and $\mathrm{Mo}, r=0.545$; $\mathrm{Cr}$ and $\mathrm{Al}$, $r=0.777$; Mo and Ni, $r=0.54$ ). Similarly, metals such as Mn and Fe which display lower concentrations in wet season than that in dry season are also positively correlated with each other (Mn and $\mathrm{Fe}, r=0.718$ ). One interpretation of these observations is that these metals in groundwater have similar hydrochemical characteristics (Chen et al. 2007) or sources in the study area as mentioned in section 3.1. In contrast, Al which displays higher concentration in wet season than that in dry season is negatively correlated with $\mathrm{Pb}$ which displays lower concentration in wet season than that in dry season ( $\mathrm{Al}$ and $\mathrm{Pb}, r=-0.424$ ), which may ascribe to the different sources of $\mathrm{Pb}$ and $\mathrm{Al}$ in groundwater of the study area as mentioned in section 3.1. $\mathrm{Cr}$ is positively correlated with Mo $(r=0.545)$, $\mathrm{Mn}(r=0.386)$ and $\mathrm{Al}(r=0.777)$, Mo is positively correlated with $\mathrm{Cr}, \mathrm{Mn}(r=0.673)$ and $\mathrm{Ni}$ $(r=0.54)$, and $\mathrm{Zn}$ is positively correlated with $\mathrm{Cu}(r=0.797)$, which may ascribe to the similar chemical behaviour. Because one of the forms of $\mathrm{Cr}, \mathrm{Mo}, \mathrm{Mn}, \mathrm{Ni}$ and $\mathrm{Al}$ in groundwater generally occur as soluble oxyanions such as $\mathrm{CrO}_{4}^{2-}$, $\mathrm{Cr}_{2} \mathrm{O}_{7}^{2-}, \mathrm{MoO}_{4}^{2-}, \mathrm{MnO}_{4}^{2-}, \mathrm{MnO}_{4}^{-}, \mathrm{NiO}_{2}^{-}$and $\mathrm{AlO}_{2}^{-}$, while one of the forms of $\mathrm{Zn}$ and $\mathrm{Cu}$ in groundwater generally occur as soluble cations such as $\mathrm{Zn}^{2+}$ and $\mathrm{Cu}^{2+}$. $\mathrm{Mn}$, positively correlated with $\mathrm{Fe}$ 
Table 3. Principal component and varimax rotated component matrix for groundwater samples in the study area $(n=29)$.

\begin{tabular}{|c|c|c|c|c|c|c|c|c|}
\hline \multirow[b]{2}{*}{ Variables } & \multicolumn{4}{|c|}{ Component matrix } & \multicolumn{4}{|c|}{ Rotated component matrix ${ }^{\mathrm{a}}$} \\
\hline & PC1 & $\mathrm{PC} 2$ & PC3 & $\mathrm{PC} 4$ & PC1 & $\mathrm{PC} 2$ & PC3 & $\mathrm{PC} 4$ \\
\hline $\mathrm{Co}$ & 0.884 & 0.004 & -0.295 & -0.035 & 0.432 & 0.168 & 0.744 & -0.319 \\
\hline $\mathrm{Cr}$ & 0.833 & -0.070 & -0.184 & -0.051 & 0.443 & 0.047 & 0.675 & -0.287 \\
\hline Mo & 0.768 & 0.094 & 0.422 & 0.185 & 0.870 & -0.047 & 0.186 & -0.131 \\
\hline $\mathrm{Al}$ & 0.745 & -0.129 & -0.484 & -0.209 & 0.142 & 0.095 & 0.858 & -0.290 \\
\hline Mn & 0.622 & 0.268 & 0.531 & 0.075 & 0.852 & 0.008 & 0.079 & 0.115 \\
\hline $\mathrm{Ba}$ & 0.559 & -0.109 & 0.076 & -0.243 & 0.356 & -0.176 & 0.482 & 0.008 \\
\hline $\mathrm{Ni}$ & 0.540 & 0.472 & 0.002 & 0.498 & 0.619 & 0.549 & 0.017 & -0.278 \\
\hline $\mathrm{Cu}$ & -0.130 & 0.871 & -0.283 & 0.153 & -0.011 & 0.896 & -0.138 & 0.238 \\
\hline $\mathrm{Cd}$ & 0.096 & 0.839 & -0.418 & 0.080 & 0.039 & 0.922 & 0.120 & 0.166 \\
\hline $\mathrm{Zn}$ & -0.057 & 0.744 & -0.425 & 0.103 & -0.092 & 0.849 & 0.022 & 0.140 \\
\hline $\mathrm{Be}$ & -0.190 & 0.691 & 0.248 & -0.524 & 0.070 & 0.296 & -0.030 & 0.869 \\
\hline $\mathrm{Hg}$ & -0.357 & 0.668 & 0.393 & -0.365 & 0.074 & 0.246 & -0.298 & 0.841 \\
\hline $\mathrm{Fe}$ & 0.573 & 0.323 & 0.606 & -0.201 & 0.813 & -0.064 & 0.159 & 0.387 \\
\hline $\mathrm{Pb}$ & -0.259 & 0.087 & 0.401 & 0.733 & 0.262 & 0.076 & -0.789 & -0.276 \\
\hline Eigenvalues & 4.199 & 3.389 & 2.001 & 1.420 & 3.146 & 2.906 & 2.788 & 2.169 \\
\hline Variance (\%) & 29.995 & 24.206 & 14.291 & 10.144 & 22.471 & 20.758 & 19.914 & 15.492 \\
\hline Cumulative (\%) & 29.995 & 54.201 & 68.492 & 78.636 & 22.471 & 43.230 & 63.144 & 78.636 \\
\hline
\end{tabular}

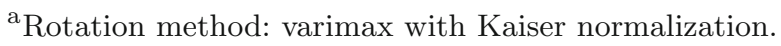

$(r=0.718)$ in the study area, also indicates similar chemical behaviour. Because the mobility of both $\mathrm{Fe}$ and $\mathrm{Mn}$ will increase due to the reduction of $\mathrm{Fe}$ and $\mathrm{Mn}$ from high valence to low valence (Shen et al. 1999), the high concentrations of $\mathrm{Fe}$ and Mn often occur naturally together in groundwater (Thamdrup 2000; Homoncik et al. 2010).

\subsection{Principal component analysis}

Principal component analysis (PCA) is a multivariate data analytic technique. It reduces a large number of variables to a small number of variables, without sacrificing too much of the information. The PCA is used to reduce groundwater chemical parameters (variables) (Davis 1986; Güler et al. 2002; Reghunath et al. 2002). In this study, the PCA was performed as an eigen-analysis of the correlation matrix and the varimax rotation was adopted to maximize the variation explained by the components (SPSS 17). Four principal components (PC1-4, with eigen-values greater than 1) resulted from the computation, explaining about $78.6 \%$ of the variance in the dataset (table 3 ). The first one is responsible for $22.47 \%$ of the total variance and is best represented by $\mathrm{Mo}, \mathrm{Mn}, \mathrm{Ni}$ and Fe. It is known that $\mathrm{Mo}, \mathrm{Mn}$ and $\mathrm{Ni}$ in groundwater generally occur as soluble oxyanions such as $\mathrm{MoO}_{4}^{2-}$, $\mathrm{MnO}_{4}^{2-}, \mathrm{MnO}_{4}^{-}$and $\mathrm{NiO}_{2}^{-}$. In addition, it has been reported that the reducing environment is mainly caused by the leakage of sewer pipe network in the study area with the values of dissolved oxygen and redox potential lower than $3 \mathrm{mg} / \mathrm{L}$ and $30 \mathrm{mv}$, respectively (Sun et al. 2009; Huang et al. 2013), and the reducing environment is one of the main factors for high concentrations of $\mathrm{Fe}$ and $\mathrm{Mn}$ in groundwater (Huang et al. 2008; Liang et al. 2009), because the mobility of $\mathrm{Fe}$ and $\mathrm{Mn}$ will increase due to the reduction of $\mathrm{Fe}$ and $\mathrm{Mn}$ from high valence to low valence (Shen et al. 1999), which leads to the desorption of Fe and $\mathrm{Mn}$ from the aquifer medium into the groundwater. Correspondingly, dissolved oxygen is positively correlated with $\mathrm{Fe}(r=0.516)$ and $\mathrm{Mn}(r=0.569)$ in this study (figure 4$)$. Above discussion implies the co-effect of human activities and natural processes for high concentrations of $\mathrm{Fe}$ and $\mathrm{Mn}$ in groundwater. Therefore, PC1 can be ascribed to the high anion exchange capacity with high concentrations of $\mathrm{Mo}, \mathrm{Mn}$ and $\mathrm{Ni}$ and reducing environment with high concentrations of $\mathrm{Fe}$ and $\mathrm{Mn}$, and characterized by the coeffect of human activities and natural processes. The PC2 explains $20.76 \%$ of the total variance and is positively correlated with ion concentration of $\mathrm{Cu}, \mathrm{Cd}$ and $\mathrm{Zn}$. It is known that $\mathrm{Cu}, \mathrm{Cd}$ and $\mathrm{Zn}$ in groundwater generally occur as soluble cations such as $\mathrm{Cu}^{2+}, \mathrm{Cd}^{2+}$ and $\mathrm{Zn}^{2+}$, indicating some similar chemical behaviour of them such as canion exchange capacity. Therefore, PC2 may be ascribed to high canion exchange capacity. The PC3 explains $19.91 \%$ of the total variance and is mainly participated by $\mathrm{Co}, \mathrm{Cr}, \mathrm{Al}$ and $\mathrm{Pb}$. It has been reported that plenty of alloy factories such as aluminum alloy (Al) and stellite ( $\mathrm{Co}$ and $\mathrm{Cr}$ ) are in the study area (Sun 

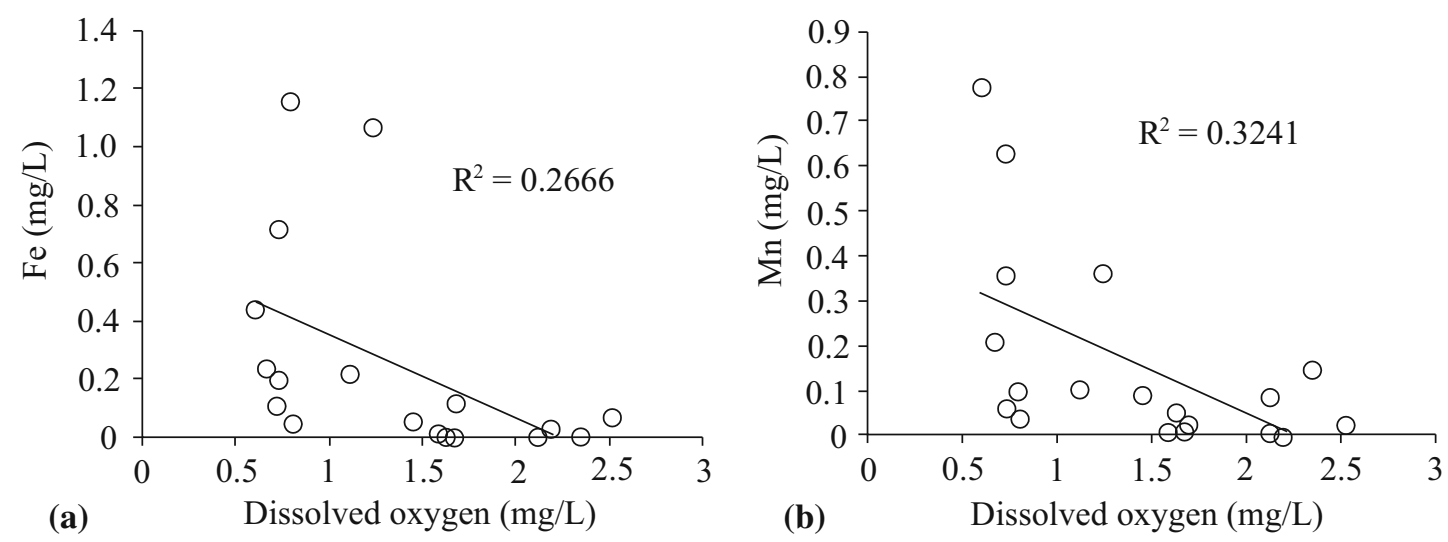

Figure 4. Correlation between the content of dissolved oxygen and Fe and $\mathrm{Mn}$ in groundwater of study area during the dry season ((a) - dissolved oxygen and Fe, (b) - dissolved oxygen and Mn).

et al. 2009), and the waste water from them is discharged into the network of sewer pipe and finally to the treatment plant. During this process, leakage of wastewater to the subsurface is inevitable due to the broken or malfunctioning pipelines (Qian et al. 2011), especially in an old town. In this case, more wastewater will enter into the groundwater in the wet season than in the dry season due to the abundant rainwater in wet season, which implies the anthropogenic source for high concentrations of $\mathrm{Co}, \mathrm{Cr}, \mathrm{Al}$ in groundwater of the study area. In contrast, as mentioned in section 3.1, the concentration of $\mathrm{Pb}$ in dry season is higher than that in wet season, and the possible reason is that $\mathrm{Pb}$ in groundwater of study area may be controlled by the aquifer itself. Therefore, PC3 may be ascribed to the seasonal factor and the anthropogenic source, because PC3 is positively correlated with $\mathrm{Co}, \mathrm{Cr}$ and $\mathrm{Al}$ and negatively correlated with $\mathrm{Pb}$. The $\mathrm{PC} 4$ explains $15.49 \%$ of the total variance and is best represented by $\mathrm{Be}$ and $\mathrm{Hg}$. As mentioned in section 3.1, the concentrations of $\mathrm{Be}$ and $\mathrm{Hg}$ in the study area are very low (especially in wet season), and both of them are mainly controlled by the natural process such as waterrock interaction and vadose zone leaching (Zhang et al. 2011). Therefore, PC4 may be ascribed to the natural process.

\subsection{Hierarchical cluster analysis}

Hierarchical cluster analysis (HCA) is used to test groundwater quality data and determine if samples can be grouped into hydrochemical groups (Anderberg 1973; Davis 1973; Alther 1979; Güler et al. 2002; Reghunath et al. 2002). In this study, the groundwater samples were classified into different groups by HCA (used the Ward method with Euclidean distance), and three groups were

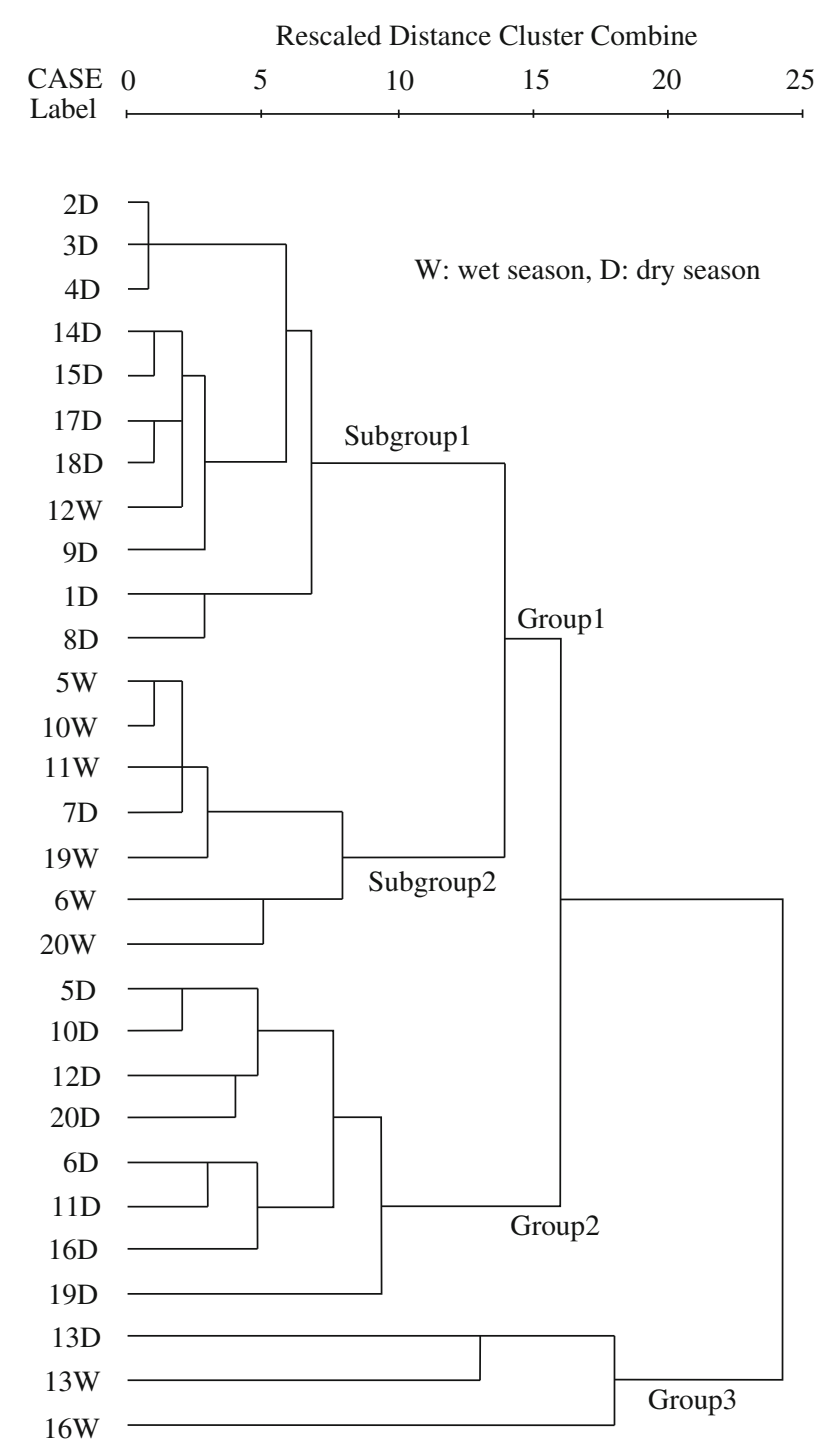

Figure 5. Dendrogram generated from the hierarchical cluster analysis by using the Ward method. 
Water quality assessment and hydrochemical characteristics of groundwater in Foshan

Table 4. Mean metal concentrations of the groups generated from HCA.

\begin{tabular}{|c|c|c|c|c|c|c|c|c|c|c|c|c|c|c|c|c|}
\hline Group & Subgroup & $n$ & $\mathrm{Be}$ & $\mathrm{Zn}$ & $\mathrm{Cu}$ & $\mathrm{Hg}$ & $\mathrm{Cd}$ & $\mathrm{Ba}$ & $\mathrm{Cr}$ & $\mathrm{Pb}$ & $\mathrm{Co}$ & Mo & $\mathrm{Mn}$ & $\mathrm{Ni}$ & $\mathrm{Al}$ & $\mathrm{Fe}$ \\
\hline & Mean & 18 & 0 & 30 & 2.5 & 0.02 & 0.05 & 52 & 8.9 & 0.9 & 0.4 & 2.3 & 71 & 3 & 132 & 97 \\
\hline \multirow[t]{2}{*}{1} & 1 & 11 & 0 & 27 & 2.2 & 0.03 & 0.05 & 59 & 4 & 0.9 & 0.3 & 1.6 & 57 & 2.9 & 106 & 45 \\
\hline & 2 & 7 & 0 & 35 & 2.9 & 0 & 0.04 & 43 & 16.8 & 0.8 & 0.6 & 3.4 & 94 & 3.3 & 174 & 177 \\
\hline 2 & & 8 & 0 & 61 & 5 & 0.05 & 0.05 & 35 & 5 & 14.7 & 0 & 3.7 & 293 & 3.5 & 30 & 365 \\
\hline 3 & & 3 & 0.1 & 256 & 11.4 & 0.11 & 0.3 & 53 & 13.2 & 1 & 0.7 & 4.5 & 654 & 4.6 & 157 & 1020 \\
\hline
\end{tabular}

Units: ion concentrations $(\mu \mathrm{g} / \mathrm{L})$.

generated (figure 5). To compare the hydrochemistry difference of three groups, the mean metal concentrations are shown in table 4. Most groundwater samples are classified into group $1(n=$ 18), which consists of two subgroups: subgroup 1 with low concentrations of $\mathrm{Zn}, \mathrm{Cu}, \mathrm{Cr}, \mathrm{Mo}, \mathrm{Mn}$, $\mathrm{Ni}$ reflects the low ion exchange capacity and indicates the opposite of PC1 and PC2, subgroup 2 with high concentrations of $\mathrm{Cr}$ and $\mathrm{Al}$ and low concentration of $\mathrm{Pb}$ reflects the characteristic of wet season and indicates the activity of PC3, which is consistent with the fact that most groundwater samples $(5 \mathrm{~W}, 6 \mathrm{~W}, 10 \mathrm{~W}, 11 \mathrm{~W}, 19 \mathrm{~W}, 20 \mathrm{~W})$ in subgroup 2 are collected in wet season except the $7 \mathrm{D}$ (figure 5). Group 2 consists of eight groundwater samples, with the high value of $\mathrm{Pb}$ and low values of $\mathrm{Cr}$, $\mathrm{Co}$ and $\mathrm{Al}$, which reflects the characteristic of dry season (as mentioned in section 3.1) and indicates the opposite of PC3. Group 3 consists of three groundwater samples, with the high values of $\mathrm{Be}, \mathrm{Zn}, \mathrm{Cu}, \mathrm{Hg}, \mathrm{Cd}, \mathrm{Mo}, \mathrm{Mn}, \mathrm{Ni}$ and $\mathrm{Fe}$, which reflects the high ion exchange capacity and reducing environment and indicates the activity of PC1, PC2 and PC4. Correspondingly, sampling sites 13 and 16 which belong to group 3 are located in the old residential area with old and rusty sewage pipes, where leakage of sewage pipes occur frequently (Sun et al. 2009). Therefore, the groundwater of sampling sites 13 and 16 are characterized by the reducing environment.

\section{Conclusions}

This report presents the first hydrochemical characteristics of metals in the Foshan of China by using multivariate analytical methods. The water quality assessment in groundwater on the aspect of metals is also discussed. Forty-five percent of groundwater in the east-central of the study area is not suitable for drinking purpose due to the high concentrations of $\mathrm{Fe}, \mathrm{Pb}$ or $\mathrm{Mn}$. The mean concentrations of $\mathrm{Fe}, \mathrm{Hg}, \mathrm{Cu}, \mathrm{Pb}$, and $\mathrm{Mn}$ in dry season are higher than in wet season. On the contrary, the mean concentrations of $\mathrm{Cd}$, Co, Zn, Ba, Cr, Mo, Ni and $\mathrm{Al}$ in wet season are higher than that in dry season.
PCA results show that four PCs are responsible for the hydrochemical variability in the groundwater samples. PC1 can be ascribed to the high anion exchange capacity and reducing environment, and characterized by the co-effect of human activities and natural processes. PC2 represents the high canion exchange capacity. PC3 may be ascribed to the seasonal factor and the anthropogenic source. PC4 represents the natural process such as waterrock interaction.

Three groups and two subgroups were generated from HCA method. Subgroup 1 reflects the low ion exchange capacity. Subgroup 2 is mainly affected by the wet season. Group 2 reflects the characteristic of dry season. Group 3 is mainly influenced by the high ion exchange capacity and reducing environment.

Due to the limits of time and funding, this study still lacks a few important datasets which will be collected in a future study. For instance, lack of some hydrogeological data such as the direction of groundwater flow and the lithology of vadose zone and aquifer. These data are the keys for predicting the variation trend of metals in groundwater of the study area, and these issues will be pursued in future.

\section{Acknowledgements}

This work was supported by the National Natural Science Foundation of China (41103059), the Basic Scientific Study Fund from the Institute of Hydrogeology and Environmental Geology, Chinese Academy of Geological Sciences (SK201410) and China Geological Survey Grant (1212011220982). The authors thank the reviewers and the editor for their constructive comments which helped to improve the manuscript substantially.

\section{References}

Alther G A 1979 A simplified statistical sequence applied to routine water quality analysis: A case history; Ground Water 17 556-561. 
Anderberg M R 1973 Cluster analysis for applications; Academic Press, New York.

Buragohain M, Bhuyan B and Sarma H P 2010 Seasonal variations of lead, arsenic, cadmium and aluminium contamination of groundwater in Dhemaji district, Assam, India; Environ. Monit. Assess. 170 345-351.

Chen K P, Jiao J J, Huang J M and Huang R Q 2007 Multivariate statistical evaluation of trace elements in groundwater in a coastal area in Shenzhen, China; Environ. Pollut. 147 771-780.

Cheung K C, Poon B H T, Lan C Y and Wong M H 2003 Assessment of metal and nutrient concentrations in river water and sediment collected from the cities in the Pearl River Delta, South China; Chemosphere 52 1431-1440.

Davis J C 1973 Statistics and data analysis in geology (New York: Wiley), 550p.

Davis J C 1986 Statistics and data analysis in geology; 2nd edn, Wiley, New York.

Edet A E, Merkel B J and Offiong O E 2003 Trace element hydrochemical assessment of the Calabar Coastal Plain Aquifer, southeastern Nigeria using statistical methods; Environ. Geol. 44 137-149.

Güler C, Thyne G D, McCray J E and Turner A K 2002 Evaluation of graphical and multivariate statistical methods for classification of water chemistry data; Hydrogeol. J. 10 455-474.

Helena B, Pardo B, Vega M, Barrado E, Fernandez J M and Fernandez L 2000 Temporal evolution of groundwater composition in an alluvial aquifer (Pisuerga River, Spain) by principal component analysis; Water Res. 34(3) $807-816$.

Homoncik S C, MacDonald A M, Heal K V, Ó Dochartaigh B É and Ngwenya B T 2010 Manganese concentrations in Scottish groundwater; Sci. Total Environ. 408 2467-2473.

Huang G X, Sun J C, Jing J H, Wang S, Du H Y, Liu J T, Chen X, Zhang Y X, Di X B and Zhi B F 2008 Distibution and origin of iron in groundwater of Zhujiang delta; Geol. China 35 531-538 (in Chinese with English abstract).

Huang G X, Chen Z Y and Sun J C 2013 Water quality assessment and hydrochemical characteristics of shallow groundwater in Eastern Chancheng District, Foshan, China; Water Environ. Res. 85 354-362.

Leung C M and Jiao J J 2006 Heavy metal and trace element distributions in groundwater in natural slopes and highly urbanized spaces in mid-levels area, Hong Kong; Water Res. 40 753-767.

Liang G L, Sun J C, Huang G X, Jing J H, Liu J T, Chen X, Zhang Y X, Du H Y 2009 Origin and distribution characteristics of manganese in groundwater of the Zhujiang River Delta; Geol. China 36 899-906 (in Chinese with English abstract).
Ministry of Land and Resources of the People's Republic of China 2008 Standards for groundwater quality, exposure draft (in Chinese).

Ouyang T P, Zhu Z Y, Kuang Y Q, Huang N S, Tan J J, Guo G Z, Gu L S and Sun B 2006 Dissolved trace elements in river water: Spatial distribution and the influencing factor, a study for the Pearl River Delta Economic Zone, China; Environ. Geol. 49 733-742.

Peng J and Wang H 2004 Variation of water environment and sustainable development of economy in Pearl River Delta; Water Res. Prot. 20 11-14 (in Chinese with English abstract).

Pizzol M, Christensen P, Schmidt J and Thomsen M 2011 Impacts of 'metals' on human health: A comparison between nine different methodologies for Life Cycle Impact Assessment (LCIA); J. Clean. Prod. 19 646-656.

Qian J Z, Liu Y, Luo S H and Chen T H 2010 Hydrological cycle, hydrogeological characteristics and mobility of arsenic in groundwater in watershed of Nanfei river, Anhui, China; Geochim. Cosmochim. Acta 74 A837.

Qian J Z, Wang L L, Zhan H B and Chen Z 2011 Urban land-use effects on groundwater phosphate distribution in a shallow aquifer, Nanfei River basin, China; Hydrogeol. J. 19 1431-1442.

Reghunath R, Sreedhara Murthy T R and Raghavan B R 2002 The utility of multivariate statistical techniques in hydrogeochemical studies: An example from Karnataka, India; Water Res. 36 2437-2442.

Shen Z L, Zhu Y H and Zhong Z S 1999 The basis of hydrogeochemistry; 2nd edn, Geological Press, Beijing, 43p (in Chinese).

Singh K P, Malik A and Sinha S 2005 Water quality assessment and apportionment of pollution sources of Gomti river (India) using multivariate statistical techniques - a case study; Anal. Chim. Acta 538 355-374.

Sun J C, Jing J H, Huang G X, Liu J T, Chen X and Zhang Y X 2009 Report on the investigation and assessment of groundwater contamination in the Pearl River Delta Area; Institute of Hydrogeology and Environmental Geology, Chinese Academy of Geological Sciences, Shijiazhuang (in Chinese).

Thamdrup B 2000 Microbial manganese and iron reduction in aquatic sediments; Adv. Microb. Ecol. 16 41-84.

Wang S G 2004 Trace elements and health; Shanghai Popular Science Press, Shanghai (in Chinese).

Zhang B, Song X F, Zhang Y H, Han D M, Tang C Y, Yu Y L and Ma Y 2012 Hydrochemical characteristics and water quality assessment of surface water and groundwater in Songnen plain, Northeast China; Water Res. 46 2737-2748.

Zhang Y X, Sun J C, Huang G X, Liu J T, Jing J H, Xiang X P, Chen X, Wang J C and Cui H W 2011 Distribution of beryllium in shallow groundwater of the Zhujiang Delta and a preliminary analysis of its origin; Geol. China 38 197-203 (in Chinese with English abstract). 